\title{
Performance of Different Tissue Culture Raised Banana Varieties on Growth Parameters
}

\author{
Balesh Goudappanavar $^{1 *}$, P. Venkatesha Murthy ${ }^{2}$ and D. Jemla Naik ${ }^{3}$ \\ ${ }^{1}$ Department of Horticulture, College of Agriculture, University of Agricultural Sciences, \\ Bengaluru-560065, India \\ ${ }^{2}$ Department of Horticulture, ${ }^{3}$ Department of Entomology, UAS, GKVK, Bengaluru, India \\ *Corresponding author
}

\section{A B S T R A C T}

\section{Keywords}

Tissue culture, Banana, Plant height, Pseudostem girth, Leaf length, Leaf breadth, Leaf area and number of leaves per plant

Article Info

Accepted:

22 June 2020

Available Online:

10 July 2020
A field experiment was conducted on "Evaluation of Elite Tissue Culture Raised Banana Varieties for Growth, Yield and Quality under Bengaluru condition" during 2018 to 2020. Total twelve tissue culture raised Banana varieties were evaluated at Department of Horticulture, University of Agricultural Sciences, Gandhi Krishi Vigyan Kendra Bengaluru. Among the twelve varieties, the maximum plant height $(342.73 \mathrm{~cm})$, pseudostem girth $(88.93 \mathrm{~cm})$, leaf length $(183.80 \mathrm{~cm})$ and number of leaves per plant (24.67) was recorded in the variety Udhayam at the time of shooting. Whereas, the result showed the minimum plant height $(212.00 \mathrm{~cm})$ in Grand Naine, minimum pseudostem girth $(69.27 \mathrm{~cm})$ in Rajapuri, minimum leaf length $(123.63 \mathrm{~cm})$ and lowest number of leaves per plant (16.73) in Swarnamukhi Nendran at the time of shooting. The variety Kamalapur Red Banana showed maximum leaf breadth $(81.40 \mathrm{~cm})$ and leaf area $\left(1.182 \mathrm{~m}^{2}\right)$ at the time of shooting. Quintal Nendran noticed the minimum leaf breadth $(70.87 \mathrm{~cm})$ and minimum leaf area $\left(0.844 \mathrm{~m}^{2}\right)$ was recorded in the variety Swarnamukhi Nendran at the time of shooting.

\section{Introduction}

Banana (Musa spp.) is one of the most important tropical fruits cultivated by man from pre-historic time in India with great socio-economic significance. The edible Banana is indigenous to Asia, probably originated in the mountainous region of Assam, Burma and Thailand. Banana is the world's largest monocious perennial herb and one of the major commercial fruit crops grown in tropics, subtropics and considered as the most economical sources of food. Banana is known for its antiquity that is interwoven with Indian heritage and culture. It is one of the most important fruits grown and consumed worldwide. It is also known as the apple of paradise, tree of wisdom, adam's fig and poor man's apple. It is the fourth most important global food commodity in terms of gross value after paddy, wheat and maize products and forms an important crop for subsistence farmers. India is the largest producer of Banana in the world and grown in 
an area of 0.89 million ha with an annual production of 31.75 million tons (NHB database 2018-19).

The edible Banana has been evolved by two wild progenitors' viz. Musa acuminata and Musa balbisiana (Simmonds and Shaphered 1955). The existing cultivars are distinguished by the number of A and B genomes Ex., AAA predominantly for desert Bananas and $\mathrm{ABB}$ for cooking Bananas. Banana belongs to the family Musaceae. It is chiefly eaten raw as a dessert fruit whereas, plantains are unpalatable when raw and must be cooked, fried, powdered, roasted or boiled before consumption. The ripe fruits are delicious and are used for table purpose. In south India, whole plant and the fruits are used extensively during weddings and festivals.

It is a monocotyledonous herbaceous perennial with underground, horizontal rhizome from which roots develop pseudostem. Bananas have a primary and adventitious root system. Primary roots originate from the surface of the central cylinder in the rhizome. Secondary and tertiary roots originate from the primary roots. The true stem is at underground and commonly referred to as a corm, but botanically the rhizome. The pseudostem is formed by the tightly packed overlapping leaf sheaths. Each leaf is about 2 to $2.5 \mathrm{~m}$ long. The pseudostem continues to grow in height as the leaves emerge one after the other and reaches its maximum height when the the flower emerges at the top of the plant. It is a monocarpic and bears male, female and hermaphrodite type of flowers.

\section{Materials and Methods}

The healthy and vigorous uniform sized tissue culture raised Banana varieties with twelve different cultivars were collected and used for trench method of planting at spacing $1.8 \mathrm{X}$
1.8 Mt. All the cultural operations were done at the proper time. One genotype was considered as a treatment and each treatment was replicated thrice. In each replication five plantswere randomly selected for recording the observations. The observations on vegetative growth parameters were recorded at monthly interval after planting till shooting stage. Plant height was measured by taking length from base of pseudostem upto bifurcation of leaves and expressed in centimeters. Pseudostem girth was measured at $5 \mathrm{~cm}$ above the ground level using tape and expressed in centimeters. The leaves were counted from each tagged plant. Leaf length was measured from leaf pedicel to leaf tip and the average was worked out and expressed in centimeters. Leaf breadth was measured from the widest point of leaf lamina and expressed in centimeters. The leaf area was calculated by average leaf length and breadth with a constant 0.80 to arrive at the actual leaf area (Hewitt, 1955). Banana bunches were harvested with a curved knife when fingers were fully developed at 75 per cent maturity, angles with less prominent and fingers in hand started to change their colour from dark green to light green. Selected bunches were weighed just after harvest. The experiment was conducted in Randomized Complete Block Design (RCBD).

\section{Results and Discussion}

The data on plant height (Table 1) showed the significant difference among the twelve varieties at different growth stages. The plant height was observed at 30,60, 90, 120, 150, $180,210,240$ DAP and at the time of shooting.

At 30 DAP, maximum plant height $(28.47 \mathrm{~m})$ was noticed in the variety Yelakki followed by Monthan $(26.47 \mathrm{~cm})$ and Rajapuri $(24.20$ $\mathrm{cm})$, The minimum plant height $(17.13 \mathrm{~cm})$ was recorded in the variety of Swarnamukhi 
Nendran. Similarly, at 60 DAP, maximum plant height $(65.33 \mathrm{~cm})$ was recorded in the varieties Yelakki, which was on par with Najangud Rasabale $(54.47 \mathrm{~cm})$ and Monthan $(53.27 \mathrm{~cm})$. The minimum plant height $(31.85$ $\mathrm{cm})$ was recorded in the varieties Kamalapur Red Banana. During 90DAP maximum plant height $(123.40 \mathrm{~cm})$ was recorded in the variety Yelakki, followed by Rajapuri (115.33 $\mathrm{cm})$, and Udhayam $(111.40 \mathrm{~cm})$. The minimum plant height $(92.67 \mathrm{~cm})$ was recorded in the variety of Swarnamukhi Nendran. Similarly at 120 DAP, the maximum plant height $(166.67 \mathrm{~cm})$ was recorded in the variety Yelakki, followed by Rajapuri $(155.13 \mathrm{~cm})$ and the minimum $(124.53 \mathrm{~cm})$ was recorded in the variety Swarnamukhi Nendran.

During 150 DAP, the maximum plant height $(189.60 \mathrm{~cm})$ was recorded in Yelakki, followed by the Udhayam $(181.60 \mathrm{~cm})$. The minimum $(159.47 \mathrm{~cm})$ was recorded in the variety Nendran and which was on par with Quintal Nendran (159.73 cm).At 180 DAP, variety Yelakki was recorded the maximum $(217.20 \mathrm{~cm})$ plant height followed by Udhayam (212.00), Whereas, the minimum plant height $(181.00 \mathrm{~cm})$ was recorded in the variety Williums. At 210 DAP, variety Yelakki recorded the maximum $(258.07 \mathrm{~cm})$ plant height followed by Quintal Nendran (247.93). Whereas, the minimum plant height $(202.60 \mathrm{~cm})$ was recorded in the variety Williums. At the time of shooting, variety Udhayam recorded the maximum $(342.73 \mathrm{~cm})$ plant height and followed by Kamalapur Red Banana $(323.23 \mathrm{~cm})$. Whereas, the minimum plant height $(212.00 \mathrm{~cm})$ was recorded in the variety Grand Naine.

Among the varieties, the maximum plant height was recorded in the variety Udhayam $(342.73 \mathrm{~cm})$ and the minimum in Grand Naine $(212.00 \mathrm{~cm})$ at the time of shooting.This might be due to its genetical characters and its vigorous growth. Similar results were obtained by following scientists. Devi et al., (2011). Medhi (1994), Sagar et al., (2016) and Behera, S., and Das, B, K. (2018).

The data on pseudostem girth (Table 2) showed the significant difference among the twelve varieties at different growth stages. Pseudostem girth was recorded at 30, 60, 90, 120, 150, 180, 210 DAP and at the time of shooting. The maximum pseudostem girth $(6.87 \mathrm{~cm})$ was recorded in variety Yelakki and it was on par with williums $(6.52 \mathrm{~cm})$ and Kamalapur Red Banana $(6.51 \mathrm{~cm})$. The minimum pseudostem girth $(4.58 \mathrm{~cm})$ was recorded in Nendran which was on par with Quintal Nendran $(4.6 \mathrm{~cm})$ at 30 DAP. At 60 DAP the maximum pseudostem girth (17.17 $\mathrm{cm})$ was recorded in variety Yelakki which was on par with Monthan (16.87 cm). Whereas, the minimum pseudostem girth $(11.31 \mathrm{~cm})$ was recorded in variety Swarnamukhi Nendranand it was on par with Nendran $(11.60 \mathrm{~cm})$, and Quintal Nendran $(11.69 \mathrm{~cm})$. The maximum pseudostem girth $(40.07 \mathrm{~cm})$ was noticed in variety Granda Naine and followed by Red Banana (34.27 $\mathrm{cm})$ and Yelakki $(32.20 \mathrm{~cm})$. The minimum pseudostem girth $(18.67 \mathrm{~cm})$ was recorded in variety Swarnamukhi Nendran and it was on par with Nendran $(19.27 \mathrm{~cm})$, and Quintal Nendran $(19.80 \mathrm{~cm})$ at 90 DAP.At 120DAP, variety Granda Naine showed the maximum pseudostem girth $(50.00 \mathrm{~cm})$ followed by Yelakki $(46.67 \mathrm{~cm})$ Whereas, the minimum pseudostem girth $(29.53 \mathrm{~cm})$ was obtained in the variety Quintal Nendran.

At the 150 DAP, the maximum pseudostem girth $(56.67 \mathrm{~cm})$ was recorded in the variety Grand Naine and it was on par with Yelakki $(54.33 \mathrm{~cm})$ and Rajapuri $(53.20 \mathrm{~cm})$. The minimum pseudostem girth $(35.02 \mathrm{~cm})$ was noticed in the variety Swarnamukhi Nendran which was on par with Quintal Nendran 
$(38.13 \mathrm{~cm})$. At the $180 \mathrm{DAP}$, the variety Grand Naine showed the maximum (62.53 $\mathrm{cm})$ pseudostem girth which was on par with the variety Kamalapur Red Banana (60.67 $\mathrm{cm})$. Whereas, the minimum pseudostem girth $(47.53 \mathrm{~cm})$ was observed in Swarnamukhi Nendran. The maximum pseudostem girth $(72.53 \mathrm{~cm}$ and $72.07 \mathrm{~cm})$ was recorded in varieties Grand Naine and Udhayam. The minimum pseudostem girth $(58.53 \mathrm{~cm})$ was recorded in Nanjangud Rasabale followed by Swarnamukhi Nendran $(63.87 \mathrm{~cm})$ variety at 210 DAP. At the time of shooting, variety Udhayam noticed the maximum pseudostem girth $(88.93 \mathrm{~cm})$ followed by Kamalapur Red Banana $(84.47 \mathrm{~cm})$. Whereas, the minimum pseudostem girth $(69.27 \mathrm{~cm})$ was obtained in the variety Rajapuri and which was on par with the variety of Swarnamukhi Nendran $(69.13 \mathrm{~cm})$.

The pseudostem girth of plant significantly differed among the varieties. The variety Udhayam $(88.93 \mathrm{~cm} \mathrm{~cm})$ recorded the maximum plant girth at the time of shooting. Whereas the minimum plant girth was recorded in the variety Swarnamukhi Nendran $(69.13 \mathrm{~cm})$ at the time of shooting. Usually cooking group plants showed vigorous growth and size of the plant was also more. Here plant height was contributing to the plant girth. These results are in line with Devi et al., (2011). Biswal et al., (2004) observed that girth of the pseudostem at the base was greatest $(88.66 \mathrm{~cm})$ in Batisha Bantala and Mendhi Bantala (Sagar et al., 2016). The same findings were obtained by Behera, S., and Das, B, K. (2018).

The data on leaf length (Table 3) showed the significant difference among the twelve varieties at different growth stages. The leaf length was recorded at 30,60, 90, 120, 150, 180,210 DAP and at the time of shooting. At 30 DAP, the maximum leaf length $(27.60 \mathrm{~cm})$ was observed in the variety Red Banana which was on par with the variety Yelakki $(25.67 \mathrm{~cm})$ and Nanjangud Rasabale $(25.00$ $\mathrm{cm})$. Whereas, the minimum leaf length $(16.67 \mathrm{~cm})$ was recorded in the variety Grand Naine. At 60 DAP, the maximum leaf length $(52.53 \mathrm{~cm})$ was observed in the variety Monthan which was on par with the variety Yelakki (50.20 cm) and Grand Naine (45.87 $\mathrm{cm})$.Whereas, the minimum leaf length $(25.67$ $\mathrm{cm})$ was recorded in the variety Nendran. The maximum leaf length $(87.00 \mathrm{~cm})$ was observed in the variety Red Banana and which was followed by the variety Kamalapur Red Banana $(82.67 \mathrm{~cm})$.Whereas, the minimum leaf length $(69.27 \mathrm{~cm})$ was recorded in the variety Rajapuri at 90 DAP.

At 120 DAP, treatment Red Banana recorded the maximum $(131.27 \mathrm{~cm})$ leaf length followed by the variety Kamalapur Red Banana $(127.07 \mathrm{~cm})$. The variety Quintal Nendran $(91.80 \mathrm{~cm})$ found the minimum leaf length. At 150 DAP, the maximum leaf length $(144.80 \mathrm{~cm})$ was observed in Kamalapur Red Bananaand it was followed by the variety Yelakki $(139.87 \mathrm{~cm})$. Whereas, the minimum leaf length $(112.93 \mathrm{~cm})$ obtained in the variety Quintal Nendran. Whereas, the maximum leaf length $(159.15 \mathrm{~cm})$ was recorded in Yelakki which was on par with variety Grand Naine $(156.47 \mathrm{~cm})$ and Williums $(155.29 \mathrm{~cm})$. The minimum leaf length $(124.87 \mathrm{~cm})$ was noticed in the variety Swarnamukhi Nendran which was on par with variety Quintal Nendran $(125.60 \mathrm{~cm})$ at 180 DAP.

The variety Grand Naine obtained the maximum $(164.13 \mathrm{~cm})$ leaf length which was on par with the variety Williums $(162.81 \mathrm{~cm})$ and Yelakki $(161.70 \mathrm{~cm})$. Whereas, the minimum leaf length $(133.47 \mathrm{~cm})$ was found in the variety Swarnamukhi Nendran at 210 DAP. At the time of shooting, the variety Uhayam recorded $(183.80 \mathrm{~cm})$ the maximum leaf length which were statistically on par 
with the variety Kamalapur Red Banana $(181.40 \mathrm{~cm})$ and Red Banana $(180.80 \mathrm{~cm})$. Swarnamukhi Nendran recorded the minimum leaf length $(123.63 \mathrm{~cm})$ compared to others.

The variety Udhayam $(183.80 \mathrm{~cm})$ recorded the maximum leaf length at shooting time (Table 3). Whereas, the lowest leaf length recorded in treatment Swarnamukhi Nendran $(123.63 \mathrm{~cm})$ at the shooting time. This might be due to its genetical characters. These results were in conformity with Hanumanthaiah (2012) and Sagar et al., (2016). The same results were obtained by Behera, S. and Das, B. K. (2018).

The data on leaf breadth (Table 4) showed the significant difference among the twelve varieties at different growth stages. The leaf breadth was recorded at 30, 60, 90, 120, 150, 180,210 DAP and at the time of shooting. At 30 DAP, the maximum leaf breadth (14.80 $\mathrm{cm}$ ) was recorded in the variety Red Banana which was on par with variety Monthan $(13.60 \mathrm{~cm})$ and Kamalapur Red Banana $(13.27 \mathrm{~cm})$. The minimum leaf breadth was recorded in the variety Nendran $(9.13 \mathrm{~cm})$ andit was on par with the variety Nanjagud Rasabale $(9.80 \mathrm{~cm})$. At 60DAP, the maximum leaf breadth $(24.53 \mathrm{~cm})$ was recorded in the variety Red Banana and it was on par with variety Monthan $(22.40 \mathrm{~cm})$ and Rajapuri $(21.80 \mathrm{~cm})$. The minimum leaf breadth was recorded in the variety Nendran $(16.24 \mathrm{~cm})$ which was on par with Swarnamukhi Nendran $(14.73 \mathrm{~cm})$.

At 90 DAP, the maximum leaf breadth $(41.87$ $\mathrm{cm})$ was recorded in the variety Kamalapur Red Banana. Which was on par with variety Nanjangud Rasabale $(41.73 \mathrm{~cm})$ and Williums $(41.67 \mathrm{~cm})$. The minimum leaf breadth was recorded in the variety Nendran $(29.07 \mathrm{~cm})$ and it was on par with the variety Swarnamukhi Nendran $(30.93 \mathrm{~cm})$. At 120
DAP, the variety Udhayam recorded the highest $(53.47 \mathrm{~cm})$ leaf breadth which were statistically on par with the variety Monthan $(52.67 \mathrm{~cm})$ and Nanjangud Rasabale (51.87 $\mathrm{cm})$. Whereas, the lowest was recorded in the variety Swarnamukhi Nendran $(44.53 \mathrm{~cm})$.

At 150 DAP, the maximum leaf breadth $(59.93 \mathrm{~cm})$ was observed in the variety Uhayam which was on par with the variety Kamalapur Red Banana $(59.40 \mathrm{~cm})$. Whereas, the minimum leaf breadth $(51.07 \mathrm{~cm})$ was observed in the variety Quintal Nendran and it was on par with Swarnamukhi Nendran $(51.47 \mathrm{~cm})$. At $180 \mathrm{DAP}$, the maximum leaf breadth $(65.79 \mathrm{~cm})$ was recorded in Grand Naine. This was on par with the variety Kamalapur Red Banana $(65.15 \mathrm{~cm})$ and Williums $(64.57 \mathrm{~cm})$. Whereas, the minimum leaf breadth $(56.47 \mathrm{~cm})$ was recorded in Quintal Nendran.

At 210 DAP, the variety Udhayam recorded the highest leaf breadth $(69.40 \mathrm{~cm})$ were statistically on par with the variety Kamalapur Red Banana $(68.44 \mathrm{~cm})$ and Williums (68.29 $\mathrm{cm})$. The variety Swarnamukhi Nendran recorded the lowest leaf breadth $(62.40 \mathrm{~cm})$. At the time of shooting DAP, maximum leaf breadth $(81.40 \mathrm{~cm})$ was observed in the variety Kamalapur Red Banana and it was on par with the Udhayam $(80.13 \mathrm{~cm})$. The minimum $(70.87 \mathrm{~cm})$ was recorded in the variety Quintal Nendran and it was statistically on par with the variety Nendran $(70.93 \mathrm{~cm})$.

The variety Kamalapur Red Banana $(81.40 \mathrm{~cm})$ recorded the maximum leaf breadth at the time of shooting. Whereas, the minimum leaf breadth was recorded in Quintal Nendran $(70.87 \mathrm{~cm})$ at the time of shooting. This might be due to its genetical characters. These results are in line with Hanumanthaiah (2012) and Sagar et al., (2016). The same results findings by Behera, S., and Das, B, K. (2018). 
Table.1 Performance of tissue cultured raised Banana varieties on plant height at different growth stages

\begin{tabular}{|c|c|c|c|c|c|c|c|c|}
\hline \multirow[t]{3}{*}{ Treatments } & \multicolumn{8}{|c|}{ Plant height (cm) } \\
\hline & \multicolumn{8}{|c|}{ Days After Planting (DAP) } \\
\hline & 30 & 60 & 90 & 120 & 150 & 180 & 210 & At shooting time \\
\hline$T_{1}:$ Grand Naine (AAA) & 17.97 & 40.93 & 100.60 & 148.47 & 177.00 & 191.40 & 202.60 & 212.00 \\
\hline $\mathbf{T}_{2}:$ Williums (AAA) & 21.00 & 38.27 & 96.67 & 146.33 & 164.00 & 181.00 & 202.60 & 237.24 \\
\hline $\mathbf{T}_{3}:$ Red Banana (AAA) & 21.47 & 37.60 & 105.60 & 130.60 & 164.93 & 194.60 & 222.60 & 319.40 \\
\hline $\mathbf{T}_{4}$ : Kamalapur Red Banana (AAA) & 20.60 & 31.85 & 98.67 & 150.13 & 180.00 & 205.93 & 238.13 & 323.33 \\
\hline $\mathbf{T}_{5}:$ Udhayam $(\mathrm{AAB})$ & 18.13 & 32.20 & 111.40 & 153.00 & 181.60 & 212.00 & 244.40 & 342.73 \\
\hline $\mathbf{T}_{6}:$ Rajapuri (AAB) & 24.20 & 44.93 & 115.33 & 155.13 & 177.07 & 201.87 & 226.93 & 244.27 \\
\hline$T_{8}$ : NanjangudRasabale (AAB) & 23.13 & 54.47 & 92.93 & 140.60 & 172.00 & 201.73 & 232.93 & 249.87 \\
\hline$T_{9}:$ Monthan (ABB) & 26.47 & 53.27 & 92.27 & 147.40 & 163.87 & 190.47 & 245.53 & 257.00 \\
\hline$T_{10}:$ Nendran (AAB) & 20.93 & 41.00 & 86.27 & 127.67 & 159.47 & 188.00 & 243.93 & 251.67 \\
\hline $\mathrm{T}_{11}$ : Quintal Nendran (AAB) & 22.53 & 38.53 & 79.93 & 129.47 & 159.73 & 188.67 & 247.93 & 254.40 \\
\hline $\mathbf{T}_{12}$ : SwarnamukhiNendran (AAB) & 17.13 & 36.87 & 92.67 & 124.53 & 161.20 & 191.00 & 242.27 & 251.27 \\
\hline S Em \pm & 0.50 & 2.90 & 1.69 & 1.41 & 1.89 & 1.36 & 2.08 & 1.42 \\
\hline CD@ $9 \%$ & 1.47 & 8.71 & 4.96 & 4.23 & 5.65 & 3.99 & 6.24 & 4.27 \\
\hline
\end{tabular}

Table.2 Performance of tissue culture raised Banana varieties on pseudostem girth $(\mathrm{cm})$ at different growth stages

\begin{tabular}{|c|c|c|c|c|c|c|c|c|}
\hline \multirow{3}{*}{ Treatments } & \multicolumn{8}{|c|}{ Pseudostem girth $(\mathrm{cm})$} \\
\hline & \multicolumn{8}{|c|}{ Days After Planting (DAP) } \\
\hline & 30 & 60 & 90 & 120 & 150 & 180 & 210 & At shooting time \\
\hline $\mathrm{T}_{1}:$ Grand Naine (AAA) & 6.05 & 15.00 & 40.07 & 50.00 & 56.67 & 62.47 & 72.53 & 75.27 \\
\hline $\mathbf{T}_{2}:$ Williums (AAA) & 6.52 & 15.63 & 30.27 & 39.87 & 42.07 & 59.87 & 70.27 & 74.27 \\
\hline $\mathrm{T}_{3}$ : Red Banana (AAA) & 6.32 & 14.01 & 34.27 & 39.83 & 46.53 & 59.93 & 70.93 & 83.33 \\
\hline $\mathbf{T}_{4}$ : KamalapurRed Banana (AAA) & 6.51 & 13.15 & 30.37 & 38.73 & 50.56 & 60.67 & 68.07 & 84.47 \\
\hline$T_{5}:$ Udhayam (AAB) & 5.69 & 14.33 & 29.33 & 42.27 & 47.73 & 58.47 & 72.07 & 88.93 \\
\hline $\mathrm{T}_{6}:$ Rajapuri (AAB) & 5.75 & 15.73 & 28.53 & 43.13 & 53.20 & 59.53 & 65.47 & 69.27 \\
\hline$T_{8}:$ NanjangudRasabale (AAB) & 5.92 & 15.07 & 23.60 & 38.93 & 39.20 & 56.00 & 58.53 & 65.07 \\
\hline$T_{9}:$ Monthan (ABB) & 6.33 & 16.87 & 26.60 & 42.40 & 45.47 & 60.60 & 70.13 & 74.40 \\
\hline$T_{10}:$ Nendran (AAB) & 4.58 & 11.63 & 19.27 & 35.93 & 43.60 & 60.40 & 68.73 & 72.13 \\
\hline$T_{11}:$ Quintal Nendran (AAB) & 4.65 & 11.69 & 19.80 & 29.53 & 38.13 & 55.87 & 66.47 & 71.60 \\
\hline $\mathbf{T}_{12}$ : SwarnamukhiNendran (AAB) & 4.95 & 11.31 & 18.67 & 30.20 & 35.02 & 47.53 & 63.87 & 69.13 \\
\hline $\mathrm{S} \mathbf{E m} \pm$ & 0.15 & 1.09 & 0.68 & 1.30 & 1.02 & 1.41 & 1.55 & 1.07 \\
\hline CD@ $@ 5 \%$ & 0.45 & 3.20 & 1.99 & 3.83 & 3.12 & 4.23 & 4.54 & 3.20 \\
\hline
\end{tabular}


Table.3 Performance of tissue culture raised Banana varieties on leaf length $(\mathrm{cm})$ at different growth stages

\begin{tabular}{|c|c|c|c|c|c|c|c|c|}
\hline \multirow[t]{3}{*}{ Treatments } & \multicolumn{8}{|c|}{ Leaf length (cm) } \\
\hline & \multicolumn{8}{|c|}{ Days After Planting (DAP) } \\
\hline & 30 & 60 & 90 & 120 & 150 & 180 & 210 & At shooting time \\
\hline $\mathrm{T}_{1}$ : Grand Naine (AAA) & 16.67 & 45.87 & 76.27 & 120.00 & 138.80 & 156.47 & 164.13 & 169.90 \\
\hline $\mathbf{T}_{2}:$ Williums (AAA) & 16.73 & 42.80 & 80.67 & 124.27 & 137.80 & 155.29 & 162.81 & 167.77 \\
\hline $\mathbf{T}_{3}:$ Red Banana (AAA) & 27.60 & 43.40 & 87.00 & 131.27 & 138.87 & 149.93 & 158.93 & 180.80 \\
\hline $\mathbf{T}_{4}$ : KamalapurRed Banana (AAA) & 19.73 & 35.87 & 82.67 & 127.07 & 144.80 & 152.97 & 157.56 & 181.40 \\
\hline $\mathbf{T}_{5}:$ Udhayam (AAB) & 20.27 & 36.00 & 79.60 & 116.67 & 135.27 & 145.73 & 158.07 & 183.80 \\
\hline $\mathbf{T}_{6}:$ Rajapuri (AAB) & 24.20 & 41.80 & 69.27 & 109.73 & 127.93 & 145.33 & 155.93 & 163.87 \\
\hline $\mathrm{T}_{7}:$ Yelakki $(\mathrm{AB})$ & 25.67 & 50.20 & 73.53 & 119.53 & 139.87 & 159.15 & 160.70 & 178.47 \\
\hline$T_{8}$ : NanjangudRasabale (AAB) & 25.00 & 41.67 & 80.80 & 123.53 & 139.33 & 148.07 & 152.93 & 171.20 \\
\hline$T_{9}:$ Monthan (ABB) & 24.00 & 52.53 & 75.20 & 116.27 & 130.60 & 140.73 & 158.60 & 168.00 \\
\hline$T_{10}:$ Nendran (AAB) & 20.33 & 25.67 & 71.20 & 92.27 & 117.67 & 135.33 & 145.47 & 164.87 \\
\hline $\mathbf{T}_{11}:$ Quintal Nendran (AAB) & 19.73 & 34.00 & 71.20 & 91.80 & 112.93 & 125.60 & 137.60 & 157.47 \\
\hline $\mathbf{T}_{12}$ : SwarnamukhiNendran (AAB) & 19.87 & 32.93 & 69.67 & 94.67 & 114.20 & 124.87 & 133.47 & 146.93 \\
\hline $\mathbf{S} \mathbf{E m} \pm$ & 0.98 & 2.85 & 0.95 & 1.39 & 1.63 & 1.45 & 1.44 & 1.88 \\
\hline CD@ 5\% & 2.86 & 8.35 & 2.79 & 4.07 & 4.78 & 4.26 & 4.23 & 5.52 \\
\hline
\end{tabular}

Table.4 Performance of tissue culture raised Banana varieties on leaf breadth $(\mathrm{cm})$ at different growth stages

\begin{tabular}{|c|c|c|c|c|c|c|c|c|}
\hline \multirow[t]{3}{*}{ Treatments } & \multicolumn{8}{|c|}{ Leaf breadth $(\mathrm{cm})$} \\
\hline & \multicolumn{8}{|c|}{ Days After Planting (DAP) } \\
\hline & 30 & 60 & 90 & 120 & 150 & 180 & 210 & At shooting time \\
\hline$T_{1}:$ Grand Naine (AAA) & 12.07 & 21.63 & 39.47 & 46.13 & 56.73 & 65.79 & 67.72 & 75.32 \\
\hline $\mathbf{T}_{2}:$ Williums (AAA) & 11.93 & 20.70 & 41.67 & 45.20 & 54.27 & 64.57 & 68.29 & 73.21 \\
\hline $\mathbf{T}_{3}:$ Red Banana (AAA) & 14.80 & 24.53 & 39.13 & 50.73 & 53.87 & 59.47 & 65.47 & 75.07 \\
\hline $\mathrm{T}_{4}$ : Kamalapur Red Banana (AAA) & 13.27 & 19.85 & 41.87 & 51.07 & 59.40 & 65.15 & 68.44 & 81.40 \\
\hline$T_{5}:$ Udhayam (AAB) & 11.33 & 19.47 & 40.33 & 53.47 & 59.93 & 64.40 & 69.40 & 80.13 \\
\hline $\mathrm{T}_{6}:$ Rajapuri (AAB) & 9.93 & 21.80 & 37.93 & 50.20 & 54.53 & 59.53 & 66.40 & 73.80 \\
\hline $\mathrm{T}_{7}:$ Yelakki $(\mathrm{AB})$ & 11.27 & 21.13 & 39.67 & 51.00 & 56.40 & 58.94 & 67.96 & 72.47 \\
\hline$T_{8}:$ NanjangudRasabale (AAB) & 9.80 & 18.67 & 41.73 & 51.87 & 55.73 & 57.00 & 64.87 & 70.27 \\
\hline$T_{9}:$ Monthan (ABB) & 13.60 & 22.40 & 39.60 & 52.67 & 55.40 & 61.07 & 67.93 & 74.40 \\
\hline$T_{10}:$ Nendran (AAB) & 9.13 & 13.67 & 29.07 & 45.93 & 53.73 & 57.73 & 65.87 & 70.93 \\
\hline $\mathbf{T}_{11}$ : Quintal Nendran (AAB) & 10.07 & 15.47 & 33.00 & 46.40 & 51.07 & 56.47 & 64.93 & 70.87 \\
\hline $\mathbf{T}_{12}$ : SwarnamukhiNendran (AAB) & 10.13 & 14.73 & 30.93 & 44.53 & 51.47 & 56.73 & 62.40 & 71.80 \\
\hline $\mathrm{S} \mathbf{E m} \pm$ & 0.47 & 1.73 & 1.04 & 0.96 & 1.34 & 1.05 & 1.40 & 0.70 \\
\hline CD@ $9 \%$ & 1.38 & 5.06 & 3.06 & 2.80 & 3.94 & 3.14 & 4.19 & 2.05 \\
\hline
\end{tabular}


Table.5 Performance of tissue culture raised Banana varieties on leaf area $\left(\mathrm{m}^{2}\right)$ at different growth stages

\begin{tabular}{|c|c|c|c|c|c|c|c|c|}
\hline \multirow[t]{3}{*}{ Treatments } & \multicolumn{8}{|c|}{ Leaf area $\left(\mathrm{m}^{2}\right)$} \\
\hline & \multicolumn{8}{|c|}{ Days After Planting (DAP) } \\
\hline & 30 & 60 & 90 & 120 & 150 & 180 & 210 & At shooting time \\
\hline$T_{1}:$ Grand Naine (AAA) & 0.016 & 0.080 & 0.182 & 0.443 & 0.630 & 0.824 & 0.904 & 1.024 \\
\hline $\mathbf{T}_{2}:$ Williums (AAA) & 0.016 & 0.082 & 0.269 & 0.450 & 0.597 & 0.802 & 0.878 & 0.988 \\
\hline$T_{3}:$ Red Banana (AAA) & 0.032 & 0.085 & 0.272 & 0.557 & 0.598 & 0.713 & 0.832 & 1.085 \\
\hline $\mathbf{T}_{4}$ : KamalapurRed Banana (AAA) & 0.021 & 0.051 & 0.277 & 0.518 & 0.688 & 0.798 & 0.838 & 1.182 \\
\hline$T_{5}:$ Udhayam (AAB) & 0.018 & 0.057 & 0.257 & 0.499 & 0.649 & 0.751 & 0.878 & 1.179 \\
\hline $\mathrm{T}_{6}:$ Rajapuri (AAB) & 0.019 & 0.074 & 0.210 & 0.441 & 0.558 & 0.692 & 0.827 & 0.969 \\
\hline$T_{7}:$ Yelakki $(A B)$ & 0.023 & 0.091 & 0.233 & 0.487 & 0.632 & 0.751 & 0.869 & 1.035 \\
\hline$T_{8}$ : NanjangudRasabale (AAB) & 0.020 & 0.063 & 0.270 & 0.513 & 0.623 & 0.675 & 0.793 & 0.963 \\
\hline $\mathrm{T}_{9}$ : Monthan (ABB) & 0.026 & 0.095 & 0.238 & 0.480 & 0.578 & 0.688 & 0.862 & 1.000 \\
\hline$T_{10}:$ Nendran (AAB) & 0.016 & 0.026 & 0.166 & 0.339 & 0.507 & 0.625 & 0.768 & 0.937 \\
\hline $\mathbf{T}_{11}$ : Quintal Nendran (AAB) & 0.016 & 0.048 & 0.188 & 0.340 & 0.461 & 0.567 & 0.714 & 0.893 \\
\hline$T_{12}:$ SwarnamukhiNendran (AAB) & 0.016 & 0.039 & 0.172 & 0.336 & 0.468 & 0.565 & 0.665 & 0.844 \\
\hline $\mathbf{S ~ E m} \pm$ & 0.001 & 0.008 & 0.005 & 0.008 & 0.013 & 0.014 & 0.009 & 0.018 \\
\hline CD@ 5\% & 0.003 & 0.024 & 0.015 & 0.024 & $\mathbf{0 . 0 3 7}$ & 0.040 & 0.025 & 0.052 \\
\hline
\end{tabular}

Table.6 Performance of tissue culture raised Banana varieties on number of leaves per plant at different growth stages

\begin{tabular}{|c|c|c|c|c|c|c|c|c|}
\hline \multirow[t]{3}{*}{ Treatments } & \multicolumn{8}{|c|}{ Number of leaves per plant } \\
\hline & \multicolumn{8}{|c|}{ Days After Planting (DAP) } \\
\hline & 30 & 60 & 90 & 120 & 150 & 180 & 210 & At shooting \\
\hline $\mathrm{T}_{1}:$ Grand Naine (AAA) & 5.87 & 8.67 & 10.80 & 12.27 & 14.40 & 16.27 & 17.40 & 18.40 \\
\hline $\mathbf{T}_{2}:$ Williums (AAA) & 5.67 & 8.27 & 10.20 & 11.27 & 13.20 & 14.93 & 16.20 & 17.80 \\
\hline $\mathbf{T}_{3}:$ Red Banana (AAA) & 5.40 & 6.87 & 9.27 & 11.00 & 13.07 & 14.53 & 16.53 & 20.73 \\
\hline $\mathbf{T}_{4}$ : KamalapurRed Banana (AAA) & 5.33 & 6.95 & 9.60 & 11.20 & 13.20 & 14.53 & 16.33 & 21.00 \\
\hline$T_{5}:$ Udhayam (AAB) & 5.20 & 7.87 & 9.73 & 12.40 & 13.80 & 15.40 & 16.47 & 24.67 \\
\hline $\mathrm{T}_{6}:$ Rajapuri (AAB) & 5.13 & 9.53 & 11.07 & 13.13 & 14.13 & 15.80 & 16.87 & 18.00 \\
\hline $\mathbf{T}_{7}:$ Yelakki $(\mathrm{AB})$ & 5.47 & 9.80 & 12.20 & 13.80 & 15.20 & 16.47 & 17.40 & 18.53 \\
\hline$T_{8}:$ NanjangudRasabale (AAB) & 5.00 & 9.07 & 10.53 & 11.73 & 13.60 & 14.73 & 16.00 & 17.87 \\
\hline$T_{9}:$ Monthan (ABB) & 4.87 & 7.87 & 9.60 & 10.67 & 12.40 & 14.20 & 15.60 & 17.40 \\
\hline$T_{10}:$ Nendran (AAB) & 4.27 & 5.73 & 8.27 & 10.67 & 12.73 & 13.87 & 15.20 & 17.07 \\
\hline $\mathbf{T}_{11}:$ Quintal Nendran (AAB) & 4.20 & 6.20 & 8.80 & 10.20 & 12.07 & 14.07 & 15.40 & 17.13 \\
\hline $\mathbf{T}_{12}:$ SwarnamukhiNendran (AAB) & 4.07 & 6.07 & 7.60 & 10.27 & 12.33 & 13.87 & 15.27 & 16.73 \\
\hline S Em \pm & 0.17 & 0.35 & 0.27 & 0.30 & 0.28 & 0.22 & 0.18 & 0.22 \\
\hline CD@ 5\% & 0.51 & 1.02 & 0.80 & 0.89 & 0.81 & 0.63 & 0.54 & 0.64 \\
\hline
\end{tabular}


The data on leaf area (Table 5) showed the significant difference among the twelve varieties at different growth stages. The leaf area was recorded at 30,60, 90, 120, 150, 180,210 DAP and at the time of shooting. At 30 DAP, the maximum leaf area $\left(0.032 \mathrm{~m}^{2}\right)$ was observed in the variety Red Banana, which was followed by variety Monthan $\left(0.026 \mathrm{~m}^{2}\right)$ and Yelakki $\left(0.023 \mathrm{~cm}^{2}\right)$. Whereas, the minimum leaf area $\left(0.016 \mathrm{~m}^{2}\right)$ was recorded in the variety Swarnamukhi Nendran. The maximum leaf area $\left(0.095 \mathrm{~m}^{2}\right)$ was found in the variety Monthan which was on par with the variety Yelakki $\left(0.095 \mathrm{~m}^{2}\right)$ and Red Banana $\left(0.085 \mathrm{~m}^{2}\right)$. Whereas, the minimum leaf area $\left(0.026 \mathrm{~m}^{2}\right)$ was noticed in the variety Nendran and it was on par with variety Swarnamukhi Nendran $\left(0.039 \mathrm{~m}^{2}\right)$ at 60 DAP.

At 90 DAP, the maximum leaf area $(0.277$ $\mathrm{m}^{2}$ ) was observed in the variety Kamalapur Red Banana which was on par with the variety Red Banana $\left(0.272 \mathrm{~m}^{2}\right)$ and Nanjangud Rasabale $\left(0.270 \mathrm{~m}^{2}\right)$. Whereas, the minimum leaf area $\left(0.166 \mathrm{~m}^{2}\right)$ was recorded in the variety Nendran. At 120 DAP, the maximum leaf area $\left(0.557 \mathrm{~m}^{2}\right)$ was obtained in the variety Red Banana which was followed by the variety Red Banana $(0.518$ $\left.\mathrm{m}^{2}\right)$. Whereas, the minimum leaf area $(0.166$ $\mathrm{m}^{2}$ ) was noticed in the variety Swarnamukhi Nendran. The maximum leaf area $\left(0.688 \mathrm{~m}^{2}\right)$ was recorded in the variety Kamalapur Red Banana and which was followed by variety Yelakki $\left(0.632 \mathrm{~m}^{2}\right)$ which was on par with variety Grand Naine $\left(0.630 \mathrm{~m}^{2}\right)$. The minimum leaf area $\left(0.461 \mathrm{~m}^{2}\right)$ was found in the variety Quintal Nendran $\left(0.461 \mathrm{~m}^{2}\right)$ at 150 DAP.

At 180 DAP, the variety Grand Naine $\left(0.824 \mathrm{~m}^{2}\right)$ obtained the maximum leaf area which was on par with the variety Williums $\left(0.802 \mathrm{~m}^{2}\right)$ and Kamalapur Red Banana $\left(0.798 \mathrm{~m}^{2}\right)$. Variety Swarnamukhi Nendran noticed the minimum $\left(0.565 \mathrm{~m}^{2}\right)$ leaf area. The maximum leaf area $\left(0.904 \mathrm{~m}^{2}\right)$ was found in the variety Grand Naine which was followed the variety Williums $\left(0.878 \mathrm{~m}^{2}\right)$. The minimum leaf area $\left(0.665 \mathrm{~m}^{2}\right)$ was recorded in the variety Swarnamukhi Nendran at 210 DAP. At the time of shooting, the maximum leaf area $\left(1.182 \mathrm{~m}^{2}\right)$ was recorded in the variety Kamalapur Red Banana which was on par with the variety Udhayam $\left(1.179 \mathrm{~m}^{2}\right)$ and Red Banana $\left(1.085 \mathrm{~m}^{2}\right)$, Whereas, the minimum leaf area $\left(0.844 \mathrm{~m}^{2}\right)$ was recorded in the variety Swarnamukhi Nendran which was at par with variety Quintal Nendran $\left(0.893 \mathrm{~m}^{2}\right)$.

The leaf area differed significantly among the twelve varieties. The variety Kamalapur Red Banana recorded the maximum leaf area of $\left(1.182 \mathrm{~m}^{2}\right)$ at the time of shooting, whereas, the minimum leaf area was recorded in the variety Swarnamukhi Nendran $\left(0.844 \mathrm{~m}^{2}\right)$ the time of shooting. It might be due to maintenance of upright growth habit and allowed maximum light interception, leaf length also contributed to increase the area of leaves. These findings are in line with Biswal et al., (2004). The same results findings by Behera, S., and Das, B, K. (2018)

The data on number of leaves per plant (Table 6) showed the significant difference among the twelve varieties at different growth stages. The number of leaves per plant was recorded at 30, 60, 90, 120, 150, 180, 210 DAP and at the time of shooting. At the 30 DAP, the maximum number of leaves per plant (5.87) was observed in the variety Grand Naine which were statistically on par with the variety Williums (5.67) and Yelakki (5.47) . The minimum number of leaves per plant (4.07) was recorded in the variety Swarnamukhi Nendran and it was at par with variety Quintal Nendran (4.20). The maximum number of leaves per plant (9.80) was observed in the variety Yelakki which 
were statistically on par with the variety Rajapuri (9.53) and Nanjangud Rasabale (9.07). The minimum number of leaves per plant (5.73) was showed in the variety Nendran and which was on par with variety Swarnamukhi Nendran (6.07) at the 60 DAP. Similarly, at the 90 DAP, the maximum number of leaves per plant (12.20) was observed in the variety Yelakki and which was followed by the variety Rajapuri (11.07). The minimum number of leaves per plant (7.60) was found in the variety Swarnamukhi Nendran.

At the 120 DAP, the maximum number of leaves per plant (13.80) was found in the variety Yelakki which were statistically on par with the variety Rajapuri (13.13) and Udhayam (12.40). The minimum number of leaves per plant (10.20) was observed in the variety Quintal Nendran and which was on par with variety Swarnamukhi Nendran (10.27). The maximum number of leaves per plant (15.20) was observed in the variety Yelakki and which was followed by the variety Grand Naine (14.40) and Rajapuri (14.13). Whereas, the lowest number of leaves per plant (12.07) was recorded in the variety Quintal Nendranat the 150 DAP. At the 180 DAP, the maximum number of leaves per plant (16.47) was observed in the variety Yelakki and which were statistically on par with the variety Grand Naine (16.27) and Rajapuri (15.80). Whereas, the lowest number of leaves per plant (13.87) was recorded in the variety Quintal Nendran and Nendran.

The maximum number of leaves per plant (17.40) was observed in the variety Yelakki and Grand Naine and which were statistically on par with the variety Rajapuri (16.87). Whereas, the lowest number of leaves per plant (15.20) was noticed in the variety Nendran at the 210 DAP. At the time of shooting, the maximum number of leaves per plant (24.67) was observed in the variety
Udhayam and followed by Kamalapur Red Banana (21.00) and Yelakki (18.53). Whereas, the lowest number of leaves per plant (16.73) was recorded in the variety Swarnamukhi Nendran and which was at par with variety Nendran (17.07).

The number of leaves per plant differed significantly among the twelve varieties. The variety Udhayam (24.67) recorded the maximum number of leaves at the time of shooting. Whereas, the minimum number of leaves was recorded in Swarnamukhi Nendran (16.73) at the time of shooting. This might be due to its genetical character. These results were in the accordance with Biswal et al., (2004). Number of leaves was the highest under Borjahajee followed by Malbhog Banana Medhi (1994) and Sagar et al., (2016). The same results observed by Behera, S., and Das, B, K. (2018).

\section{References}

Annonymous, NHB data 2018-19.

Behera, S., and Das, B, K., 2018., Assessment of genetic variability, heritability and genetic advance for yield components in some cooking Banana genotypes (Musa Spp.).J. of Pharmacognosy and Phytochemistry. 7(6): 1700-1703.

Biswal, M. K., Lenka, P. C. and Dash, D. K., 2004, Evaluation of culinary Banana genotypes. Orissa J. Hort, 32 (1): 6365.

Devi, P. S., Thangam, M., Ladaniya, M. S. and Korikanthimath, V. S., 2011, Evaluation of local Banana cultivars under coconut shade in Goa. J. Biol. Chem. Research., 28: 63-76.

Hanumanthaiah, M. R., 2012, Response of soil and foliar application of silicon on growth, yield and quality of Banana cv. Elakkibale Under Hill Zone of Karnataka. MSc (Hort.), Thesis University of Horticultural Sciences, 
Bagalkot.

Hewit, C. W., 1955, Leaf analysis as a guide to the nutrition of Bananas. Emp. $J$. Exp. Agric., 23: 11-16.

Medhi, G. 1994. Performance of some cultivars of Banana (Musa paradisiaca) in Assam. Haryana Journal of Horticultural Sciences. 23: 181-85.

Sagar, B. S., Raju, B and Sahithya, B. R., 2016, Correlation Studies on Different
Banana Genotypes Between Growth and Yield Attributes, The Bioscane, an Int. Quateral J. of Life Sci., 11(4): 3065-3069.

Simmonds, N.W. and Shephered, K., 1955, The taxonomy and origin of the cultivated Bananas. J. Linn. Soc. London Bot., 55:302-312.

\section{How to cite this article:}

Balesh Goudappanavar, P. Venkatesha Murthy and Jemla Naik, D. 2020. Performance of Different Tissue Culture Raised Banana Varieties on Growth Parameters. Int.J.Curr.Microbiol.App.Sci. 9(07): 3600-3610. doi: https://doi.org/10.20546/ijcmas.2020.907.420 